\title{
Primitive techno-economic study of bio- diesel and bio-active compound production from microalgae
}

\author{
Sayeda M. Abdo ${ }^{1 *}$, Guzine I. El Diwani ${ }^{2}$, Kamel M. El-Khatib², Sanaa A. Abo El-Enin², Mohammed I. El-Galad ${ }^{3}$, \\ Haidy S. Basily ${ }^{4}$ and Gamila H. Ali ${ }^{1}$
}

\begin{abstract}
Background: Microalgae cells can be identified as a potential source for new and renewable energy. The economic investigation for biodiesel and bio-active compound production from the microalgae community (Bloom), which are collected from the high rate algal pond (HRAP) constructed to treat municipal wastewater at Zenin wastewater treatment plant, Giza, was the main target of study.

Results: The microscopical examination showed that Scenedesmus obliquus is the dominant species. The total carotenoids were extracted using jojoba oil and determined by high-performance liquid chromatography (HPLC) to reach $81.44 \mu \mathrm{g} / \mathrm{g}$. The biodiesel production through acid transesterification reaction recorded $70.6 \%$ of fatty acid methyl ester content with high cetane number (44) and low acid value. Such results prove that the obtained biodiesel has better ignition quality. The total phenolic and flavonoid compounds have been derived from the remaining biomass to give $5.36 \pm 0.03$ and $1.50 \pm 0.19 \mathrm{mg} / \mathrm{g}$ respectively. Finally, total proteins and carbohydrates content in algal cells were recorded 54.3 and $1.5 \mathrm{mg} / \mathrm{g}$ successively
\end{abstract}

Conclusion: The preliminary economic evaluation showed that the production of biodiesel and carotenoids from the microalgae growing in municipal wastewater can be considered, as a techno-economic feasible process.

Keywords: High rate algal pond, Biodiesel, Bioactive compounds, Preliminary techno-economic evaluation

\section{Introduction}

The microalgae were known as a biofuel production source to replace conventional petroleum fuel. They are well known as producers for several natural compounds used in food technology, (Yen et al. 2013). Microalgae have a big tolerance at various conditions of environmental and can be grown in arid regions. (Delgadillo-Mirquez et al. 2016). Microalgae have a way of removing carbon, nitrogen, and phosphorus from the wastewater with increasing their biomass for biofuel and bio-active compound production (Marazzi et al. 2020; Yoshitani 2014). The algae growing in high rate algal pond (HRAP) produce oxygen as a photosynthesis by-product. This oxygen

\footnotetext{
* Correspondence: sayedamohammed2015@gmail.com

${ }^{1}$ Water Pollution Research Department, National Research Centre, Giza, Egypt Full list of author information is available at the end of the article
}

oxidizes the organic compounds in the wastewater and the carbon dioxide is fixed in the algal cells (Molazadeh et al. 2019). The high rate algal ponds (HRAPs) are one of the best wastewater treatment systems to produce a large amount of algal biomass (Craggs et al. 2011; Kiepper 2013). HRAPs are a more efficient sterilization system than the conventional one because they are enhancing the rate of sunlight and rest the photo-oxidation for contaminants of dissolved organic compounds (Wollmann et al. 2019).

Many species of microalgae are capable of growing in wastewater media by utilizing the present carbon, phosphorus (P) and nitrogen (N) (Whitton et al. 2015).

The microalgae for wastewater remediation are a source of biofuel and multiple bio-active compounds 
that can be used in the nutraceutical and pharmaceutical industries (Delrue 2016; Mata-Gómez 2014).

Microalgae biomass can be used directly as feedstock in different chemical conversion processes as, pyrolysis, gasification, fermentation, liquefaction, or extraction of oil to produce biodiesel (Halim et al. 2011). Algal biodiesel is non-toxic, biodegradable, and reduced levels of $\mathrm{CO} 2, \mathrm{CO}$, and $\mathrm{SO}_{\mathrm{x}}$ emissions (Pittman et al. 2012).

Due to the high physiological diversity of microalga, they are one natural source providing novel biologically active substances such as carotenoids, phenols, flavonoids, proteins, and carbohydrates (Michalak and Chojnacka 2015; Hielscher-Michael et al. 2016). The concentration of each compound depends on the nature of the organism, the environmental conditions, and the physiological state of the culture itself (Zhang et al. 2019)

Carotenoids, also called tetraterpenoids, are organic pigments (yellow, red, orange) that are produced by plants and algae, so they can be used as natural food colorants. They have several industrial uses in health supplements and cosmetics products, with high antioxidant properties. The main algal carotenoids are astaxanthin, $\beta$-carotene, and lutein (Markou and Nerantzis 2013). Carotenoids are widely used in suntan, skincare, hair care, and anti-aging products. (Guedes et al. 2011).

Phenolic and flavonoid compounds in algal cells are secondary metabolites and reported as antioxidants, antibacterial, anti-inflammatory, anti-cancer agents, and free radical scavengers (Abd El-Baky et al. 2009; Goiris et al. 2012).

Proteins and carbohydrates are the main components of algal cells, which are characterized by antibacterial, antioxidative, anti-inflammatory, antitumor, and antiviral properties (Lopez et al. 2010).

Recently, it is necessary to achieve a potent economic analysis that can cover the conversion process of all algal biomass to biodiesel and bioactive products. Such analysis must be supplied at every step of the process for supporting the research and the investment and consequently, to the success of this technology.

The work aims to evaluate the economic investment of the microalgae community for the production of biodiesel and bio-active compounds without cost for algae cultivation and obtaining of a clean environment. The microalgae communities are collected from the high rate algal pond (HRAP) to treat municipal wastewater at Zenin wastewater treatment plant, Giza.

\section{Materials and methods}

Microalgae communities (Bloom) were collected from the high rate algal pond (HRAP) constructed to treat municipal wastewater at Zenin wastewater treatment plant, Giza, through the project of "Biodiesel production from microalgae in stabilization pond for municipal wastewater treatment" in Water Pollution Research Department, NRC, and Giza, Egypt., and the wet biomass was dried overnight at $60{ }^{\circ} \mathrm{C}$. Jojoba oil, citric acid, potassium hydroxide, and solvents used for extraction were of analytical grade, and those used for chromatography were of HPLC grade.

\section{Extraction of carotenoids}

Ten milliliters of distilled water was added to $10 \mathrm{~g}$ of dry algae cells to form a slurry, $5 \mathrm{~g}$ of dry granular citric acid was further added to the slurry, and then jojoba oil was added as (1:1) w/w of algal biomass. The mixture was homogenized at $(1000 \mathrm{rpm})$ for approximately $15 \mathrm{~min}$ [Homogenizer Model Wise Tis HG-150, Germany]. The slurry reaction mixture is stirred for 45 minutes at a temperature of $80^{\circ} \mathrm{C}$; then, the mixture is neutralized using potassium hydroxide, and the temperature is reduced to $45^{\circ} \mathrm{C}$. Centrifugation of the mixture to obtain two layers, the upper layer was the carotenoid with jojoba oil; the lower layer was biomass and water. The upper layer is decanted and stored for HPLC analysis (Basily et al. 2018), and the remaining biomass is then used for getting of lipid, phenolic flavonoid, protein, and carbohydrate.

\section{Ultrasound-assisted bath lipid extraction (UABE)}

The remaining algal biomass is mixed with a $60 \mathrm{ml}$ mixture of $\mathrm{n}$-hexane and isopropanol $(3: 2 \mathrm{v} / \mathrm{v})$. The extraction process is performed in the ultrasonic bath (Model WUC-D10H, $60 \mathrm{~Hz}, 230$ volts, $665 \mathrm{~W}, 3$ AMPS, Germany) at room temperature $\left(30-35^{\circ} \mathrm{C}\right)$ under a reflux condenser for $30 \mathrm{~min}$. Cell residue was removed by filtering through filter paper. The filtrate of the solvent mixture was evaporated using a rotary evaporator to enable the gravimetric quantification of total lipid extract (Abo El-Enin et al. 2016). The crude lipid was redissolved in $\mathrm{n}$-hexane (approximately $5 \mathrm{ml}$ ) for further analysis. The remaining biomass is used for getting of phenolic flavonoid, protein, and carbohydrate.

\section{Biodiesel production}

After lipid extraction, the conventional transesterification reaction is carried out using $\mathrm{H}_{2} \mathrm{SO}_{4}$ acid (98\% concentration) as a catalyst (100\% of the lipid mass) and methanol as solvent (methanol/lipid $30: 1 \mathrm{ml} / \mathrm{g}$ ). When the reaction mixture (oil and methanol) reached $60{ }^{\circ} \mathrm{C}$, sulfuric acid was added to start the reaction time $(4 \mathrm{~h})$. After complete reaction, the excess alcohol is removed by evaporation using a rotary evaporator. The reaction mixture was transferred to a separating funnel after adding hexane to facilitate settling. Then, the mixture was partitioned into two distinct phases: a top hexane layer containing fatty acid methyl ester FAME and a bottom 
layer containing glycerol. Then, hexane phase was washed with distilled water and collected in a preweighed flask and left to dry at $60{ }^{\circ} \mathrm{C}$ till constant weight (Doma et al. 2016).

\section{Determination of total phenolic content}

One gram of algal cells was re-suspended in $20 \mathrm{ml}$ of $80 \%$ ethanol, homogenized for $3 \mathrm{~min}$ at $4{ }^{\circ} \mathrm{C}$ to disrupt cells. The homogenate was centrifuged at $2000 \mathrm{rpm}$ for $15 \mathrm{~min}$ at $4{ }^{\circ} \mathrm{C}$. The resulting supernatant was centrifuged again at $2000 \mathrm{rpm}$ for $10 \mathrm{~min}$. the residue was repeatedly extracted with the same solvent until they were colorless. Then, the supernatant was filtered through Millipore filters. The filtrate was evaporated to dryness to give a crude algal ethanolic extract (enrich in phenolic compounds) and immediately analyzed. Total phenolic content was determined with Folin-ciocalteu reagent (Basily et al. 2018) using gallic acid as a standard phenol compound. The concentration of total phenol content was measured as milligram of gallic acid equivalent (GAE in $\mathrm{mg} / \mathrm{g}$ of the sample). All the determinations were carried out in triplicates (Sarojini et al. 2013).

\section{Determination of total flavonoids}

One gram of algal biomass was crushed in the motor, added $5 \mathrm{ml}$ of distilled water, centrifuged at $1000 \mathrm{rpm}$ for $15 \mathrm{~min}$, and incubated at $4{ }^{\circ} \mathrm{C}$ for $20 \mathrm{~min}$. Then, it was transferred to a water bath adjusted at $100^{\circ} \mathrm{C}$ for 20 min. The supernatant was filtrated through filter paper No. 1; the filtrate was adjusted to $25 \mathrm{ml}$ with $95 \%$ methanol solution and incubated at room temperature for $48 \mathrm{~h}$ for the determination of flavonoid content. Total flavonoid was measured by a colorimetric assay (Shashank and Abhay 2013).

\section{Determination of carbohydrates content}

A sample of algae biomass weighing $0.1 \mathrm{~g}$ was added to $25 \mathrm{ml}$ of $1 \mathrm{~N} \mathrm{H}_{2} \mathrm{SO}_{4}$, and the mixture was hydrolyzed for $2 \mathrm{~h}$ on a boiling water bath. At the end of hydrolysis, a flocculent precipitate was noticed. This was freed of sulfate by precipitation with barium carbonate, filter and complete to $100 \mathrm{ml}$, and mix $1 \mathrm{ml}$ of the filtrate with 1 $\mathrm{ml} 5 \%$ phenol and $5 \mathrm{ml}$ concentrated $\mathrm{H}_{2} \mathrm{SO}_{4}$ to measure the carbohydrate content at $485 \mathrm{~nm}$ (Basily et al. 2018).

\section{Determination of total protein content}

Total protein content was determined by the Kjeldahl method and then multiplied with a factor 6.25 to give the total protein content (Dubois et al. 1956) $0.5 \mathrm{~g}$ of catalyst, and $2 \mathrm{ml} \mathrm{H}_{2} \mathrm{SO}_{4}$ was added to $0.2 \mathrm{~g}$ of algal sample, digested until the color becomes clear. Two drops of methyl orange indicator and $15 \mathrm{ml}$ of $40 \%$ $\mathrm{NaOH}$ solution were added to the clear sample and transfer to the distillation apparatus. The liberated ammonia is received in $10 \mathrm{ml}$ of $4 \%$ boric acid and 2 drops of Tashiro's indicator. When the liberation of ammonia stopped, the solution was titrated against $0.01 \mathrm{~N}$ $\mathrm{HCl}$ (catalyst $-10 \mathrm{~g} \mathrm{~K}_{2} \mathrm{SO}_{4}+1 \mathrm{~g} \mathrm{CuSO}_{4} \cdot 5 \mathrm{H}_{2} \mathrm{O}+0.5 \mathrm{~g}$ selenium) (Tashiro's indicator $0.24 \mathrm{~g}$ methylene blue + $0.375 \mathrm{~g}$ methyl red in $30 \mathrm{ml}$ methyl alcohol).

\section{High-performance liquid chromatography (HPLC)}

HPLC analysis was carried out using Agilent Technologies 1100 series liquid chromatograph equipped with an autosampler and a diode-array detector $(461 \mathrm{~nm})$. The analytical column was Eclipse XDB-C18 $(150 \times 4.6 \mu \mathrm{m}$; $5 \mu \mathrm{m}$ ) with a C18 guard column (Phenomenex, Torrance, CA). Chromatograms were monitored at $450 \mathrm{~nm}$; the mobile phase was acetonitrile-2-propanol-ethyl acetate $(40: 40: 20, \mathrm{v} / \mathrm{v} / \mathrm{v})$; the flow rate was $0.8 \mathrm{~mL} \mathrm{~min}^{-1}$, the pressure as $850-1050 \mathrm{psi}$; and the recorder chart speed was $0.5 \mathrm{~cm} \mathrm{~min}^{-1}$. The carotenoid extracts obtained as mentioned above were dissolved in the mobile phase $(1$ $\mathrm{mL}$ ), filtered through a $0.450 \mu \mathrm{m}$ membrane disc (Schleicher and Schull, Dassel, Germany), and injected into chromatograph (injection volume, $10 \mu \mathrm{L}$ ). The column was regenerated by washing with 2-propanol after analysis, then equilibrated with the mobile phase.

\section{Gas chromatography analysis}

The fatty acid profiles of algal oil are determined using gas chromatography (GC) provided with a split automatic injector and silica capillary column DB-5 (length $60 \mathrm{~m}$; ID $0.32 \mathrm{~mm}$ ). Helium is used as carrier gas at a flow rate of $1 \mathrm{~mL} / \mathrm{min}$. The column was held at $150^{\circ} \mathrm{C}$ for $1 \mathrm{~min}$ and ramped to $240^{\circ} \mathrm{C}$, at a rate of $30^{\circ} \mathrm{C} / \mathrm{min}$, and held at $240^{\circ} \mathrm{C}$, for $30 \mathrm{~min}$. Standards are used to give rise to well-individualized peaks that allow the identification of the fatty acid composition.

\section{Results \\ Carotenoid and lipid content in algal biomass collected from HRAP}

The carotenoid and lipid extraction from the algal cells are affecting each other, as shown in Table 1, where the lipid percentage extracted before carotenoid recorded higher value than its percentage if extracted after the carotenoid extraction. The same conclusion for carotenoid content, but the decreasing percentage of carotenoid content if extracted after lipid extraction is very high.

\begin{tabular}{|c|c|c|}
\hline Sample name content, $\mu \mathrm{g} / \mathrm{g}$ & Lipid \% & Carotenoid \\
\hline Lipid before carotenoid & 6 & 48.839 \\
\hline Lipid after carotenoid & 5.5 & 81.144 \\
\hline
\end{tabular}




\section{Biodiesel properties}

The fatty acid methyl ester (FAME) obtained from algal oil (collected from the HRAP) has a brownish-yellow color with a yield $70.6 \%$ and purity percentage $85 \%$.

\section{Total phenolic and flavonoid content}

As shown in Table 2, the total phenolic $(5.3 \mathrm{mg} / \mathrm{g})$ higher than the total flavonoid content $(1.5 \mathrm{mg} / \mathrm{g})$ in the microalgae cells was collected from the HRAP (Rahul et al. 2016).

\section{Total carbohydrates and protein content}

The total carbohydrates content of the biomass collected from HRAP was $600 \mathrm{mg} / \mathrm{g}$ (Table 3). The higher amount of algal biomass from carbohydrates is present in different forms, such as glucose, sugars, polysaccharides, and starch (de Jesus Raposo et al. 2013). The dry microalgae can be used as foods or feeds without restrictions since their sugars are digestible (Skjanes et al. 2013).

The results showed that the total protein content was $78.57 \mathrm{mg} / \mathrm{g}$. Microalgae are able to enhance the nutrition value of food industries and thus affect positively on the human and animal health.

\section{Techno-economic feasibility study}

Feasibility analysis is a useful technique which used to guide the research for achievement economical and viable outcome. The economic modeling can be used to estimate different processes, in order to define the project balance through the economic value and measure the obscurity of project risks financially and technically. It will provide and describe the feasibility study of the process for using in our investigation.

The analysis steps will be as follows:

- Collect all data of the laboratory experiments.

- Use the Aspen HYSYS ${ }^{\mathrm{TM}}$ software of process engineering to design the model.

- According to the principles in the literature, it can define the process' equipment size (Kern 1950; McCabe et al. 1993; Bleakley and Hayes 2017).

- Both the costs and investments of the operation will be determined.

Table 2 Total phenolic and flavonoid content in algal biomass from HRAP

\begin{tabular}{llll}
\hline Sample name & Absorbance & $\mathrm{mg} / \mathrm{g}$ & Mean value \\
\hline Total phenolic & 0.1722 & 5.38 & $5.36 \pm 0.03$ \\
& 0.171 & 5.34 & \\
Total flavonoid & 0.3778 & 1.63 & $1.50 \pm 0.19$ \\
& 0.3693 & 1.36 & \\
\hline
\end{tabular}

Table 3 Total carbohydrates and protein content in algal biomass from HRAP

\begin{tabular}{ll}
\hline Sample name & Mean value \\
\hline Carbohydrates & $600 \pm 0.01 \mathrm{mg} / \mathrm{g}$ \\
Proteins & $78.57 \pm 2 \mathrm{mg} / \mathrm{g}$ \\
\hline
\end{tabular}

- In the end, the return of investment (ROI \%) and breakeven point are calculating to evaluate the process.

\section{The model of process}

The process model was constructed by using a simulation of the Aspen HYSYS ${ }^{\mathrm{TM}}$ V8.4 software. Defining the chemical components is the first step in setting up a process model. The microalgae oil obtained will be considered as triolein $\left(\mathrm{C}_{57} \mathrm{H}_{104} \mathrm{O}_{6}\right.$ as the most triglycerides present in microalgae oil and the product of biodiesel as methyl oleate $\left(\mathrm{C}_{19} \mathrm{H}_{36} \mathrm{O}_{2}\right)$. The "Hypo Manager" tool of HYSYS $^{\mathrm{TM}}$ was used to define these components which are not present in the library, like carotenoids.

The model of NRTL thermodynamic was used due to the presence of methanol as a very high polar component (Sinnott 2005). On the other hand, the operating conditions according to the laboratory experiments that $\%$ oil content in algae is 5 , the \% carotenoids in algae are 0.00655 , and $20 \%$ of algae solution, of concentration $2 \mathrm{~g} /$ $\mathrm{L}$, is removed per day from the ponds; the acid catalyzed transesterification process was used due to the high free fatty acids in microalgae oil.

Biodiesel production in industrial scale in Egypt is the first step. The capacity of built plants will be small or medium. The study is based on 10,000 ton/year of biodiesel production, where the process of biodiesel production from microalgae is divided into five steps: cultivation (Fig. 1), harvesting and extraction of carotenoids (Fig. 2), extraction of oil (Fig. 3), transesterification (Fig. 4), and purification of products (Fig. 5).

The main units for the process are reactors, separators, distillation column, pumps, and heat exchangers. The microalgae was cultivated using an open ponds system with $20 \%$ removed continuously to maintain a constant growth rate. The water was then removed using two stages of filtration (centrifuge then decanter centrifuge) and was dried before oil extraction step.

Since complete information about the process kinetics was not accessible, the transesterification reaction was described by a simple reactor model for oil conversion 97\% to FAME. Methanol recovery was done using multistage distillation. The simulations of biodiesel purity could not be reached with a simple unite of flash, because of the high difference between the boiling point of methanol $\left(65^{\circ} \mathrm{C}\right)$ and that of FAME $\left(320^{\circ} \mathrm{C}\right)$ at 1 


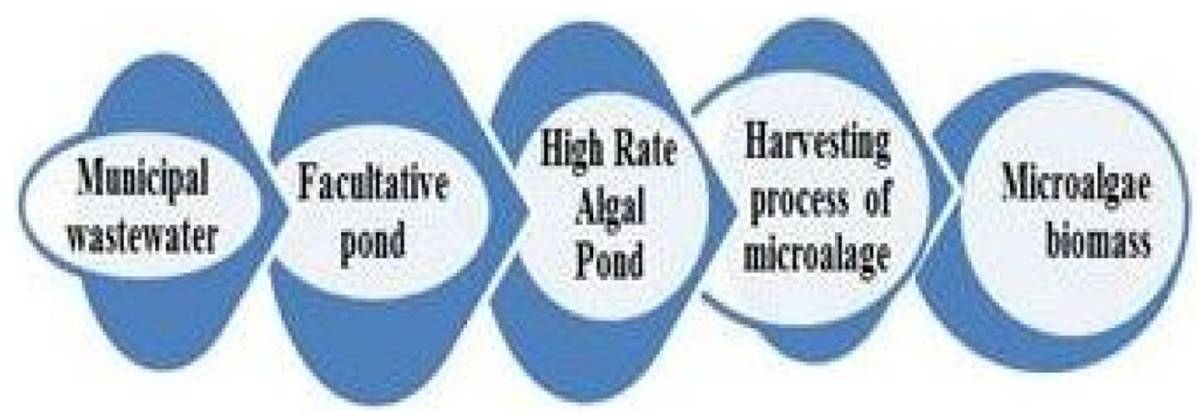

Fig. 1 Cultivation flow sheet

atmosphere. So, the produced biodiesel purity (i.e., 99.65 wt.\%) in the present study was measured using ASTM standard method (Aspen Tech Inc. 2005). The steady-state simulation process was concluded by HYSY $S^{\mathrm{TM}}$, after setting up the models of operating units and input information to obtain operating conditions for each step as well as energy and mass balance.

\section{Economic estimation}

There are different factors to evaluate the project such as environmental and technical factors besides the economic evaluation as an important one. The economic estimation is indicating either the project will loss or profit money. For biodiesel plant, the total manufacturing cost, fixed capital cost, and the breakeven point (i.e., the economic evaluation) can be determined through some factors, such as process technology, plant capacity, and cost of raw material and chemical.

Some assumptions were used for this economic evaluation:
- Operating time was set at $8000 \mathrm{~h} /$ year.

- Heating media were set from pressure steam (low and high).

- For cooling, the water was used.

Table 4 is showing the cost of catalysts, raw materials, and products as in the Egyptian local market. According to the total manufacturing cost (TMC), total capital investment (TCI), return on investment (ROI \%), and breakeven point, the process was evaluated. In this work, the assessment performed is assorted as a "study estimate" with accuracy expected from $+30 \%$ to $-20 \%$ (Turton et al. 2009). Although the results of such a study do not reflect the final cost of chemical plant constructing, the technique is useful to compare competing processes.

\section{The process evaluation}

The investment of total capital (TCI) as shown in Table 5 is involving the costs of everything like installation, instrumentation, electrical, buildings, designs, storage,

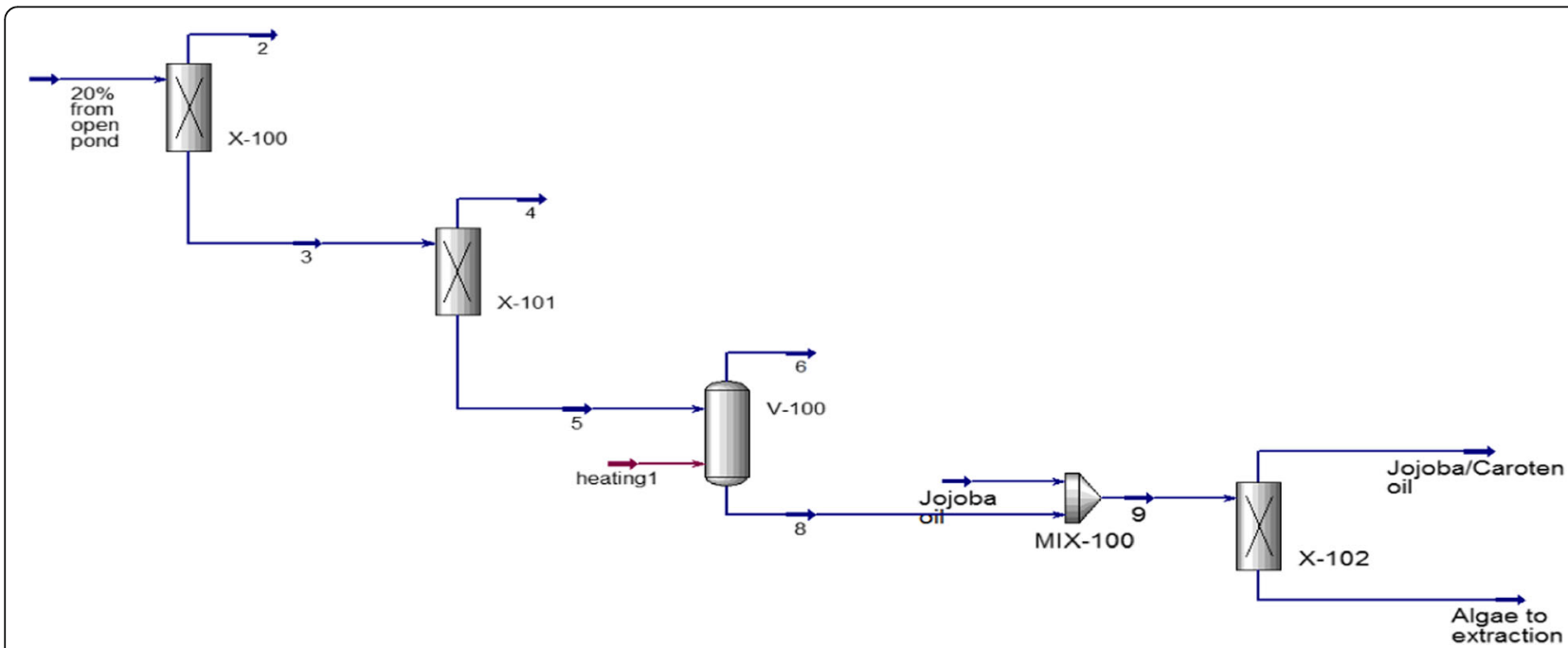

Fig. 2 Harvesting and extraction of carotenoids flow sheet, where (X-100)centrifuge, (X-101) decanter centrifuge, (V-100) sand bed dryers, (MIX100) mixer, and (X-102) gravity settler 


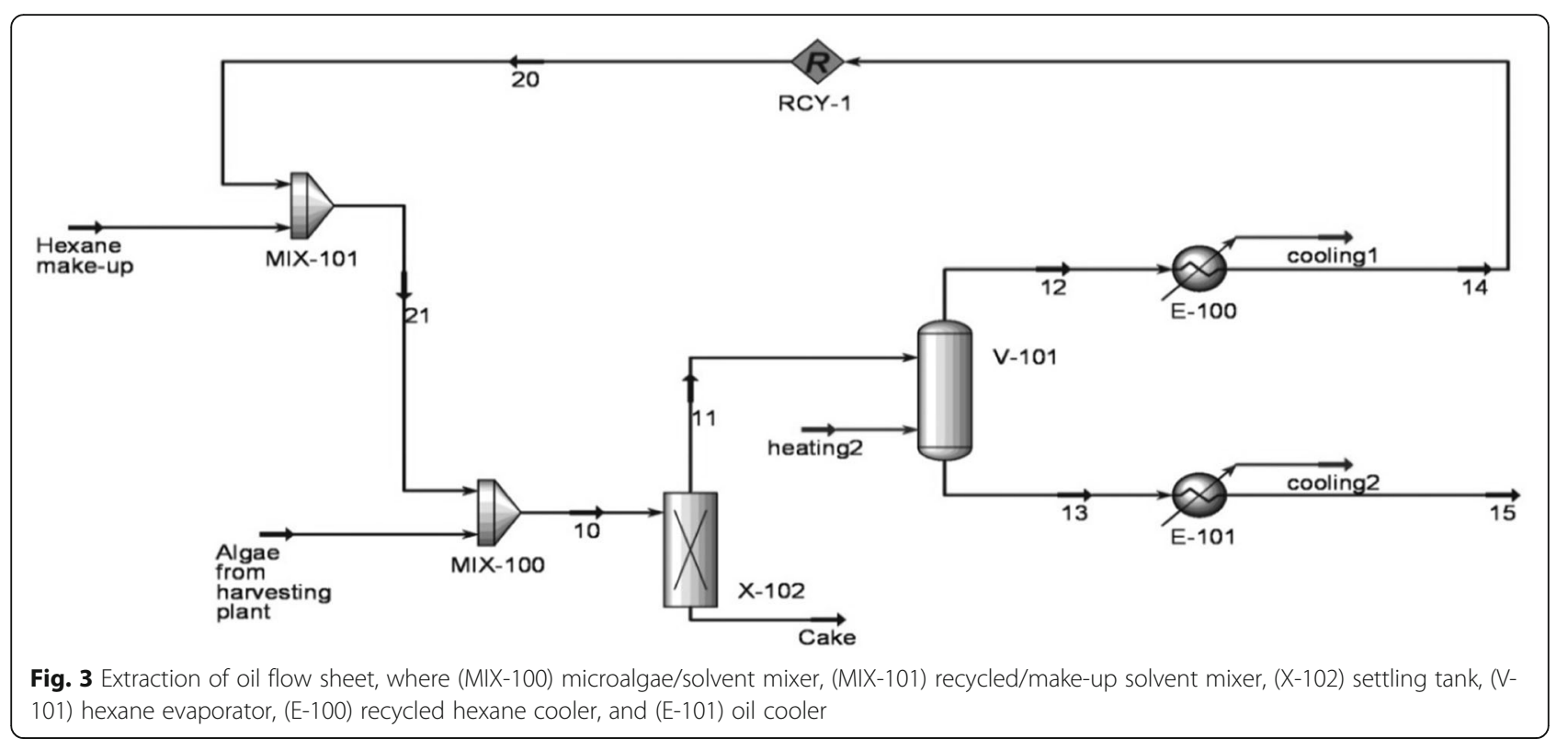

contingencies, utilities, and contractor's fee (Zhang et al. 2003) besides the investment of working capital (WCI) which is recording $8 \%$ of TCI.

The cost of manufactured products must be calculated in order to decide their selling price including the profit. As shown in Table 6, the manufacturing cost is including the outlay of shipping process, supervision, labor, plant overhead, depreciation, rent costs of raw materials, insurance, maintenance, royalties, and the raw materials cost, besides cost of indirect manufacturing (IDMC) which is being $20 \%$ of TMC. The cost of labor was evaluated by $\$ 546,965$, for a continuous plant with three 8 -h shifts/day and the operators worked 48 weeks per year.

To get ROI, total profit must be calculated. Biodiesel was the main product in this process and cost about $\$ 1235 /$ ton, while jojoba oil with carotenoids cost $\$ 4500$ / ton. The extracted microalgae cake and produced glycerol are considered as byproducts for the process. The total products' sales cost equals to $\$ 1,077,259,539$, and the net profit will be the result of subtracting TMC from total sales' cost.

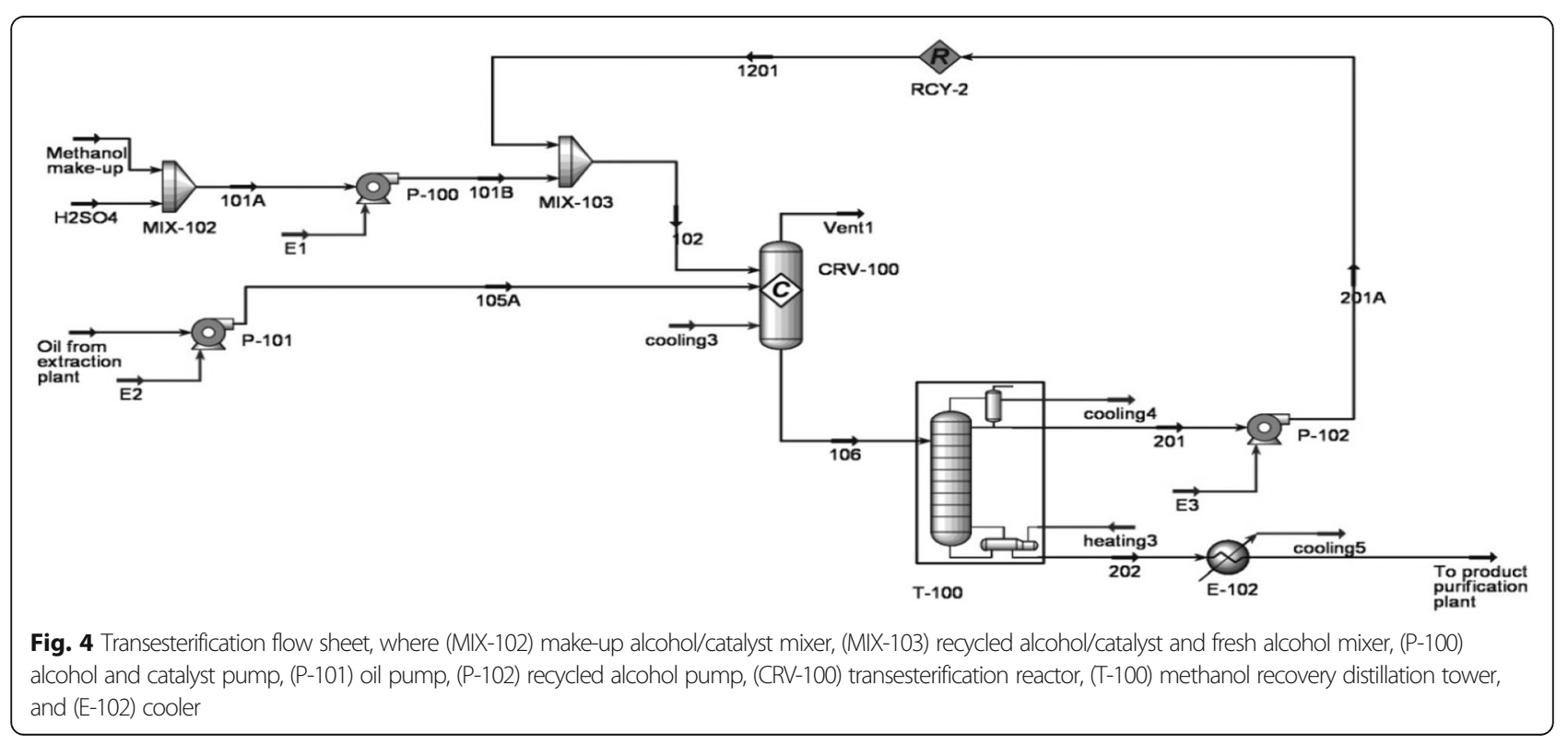




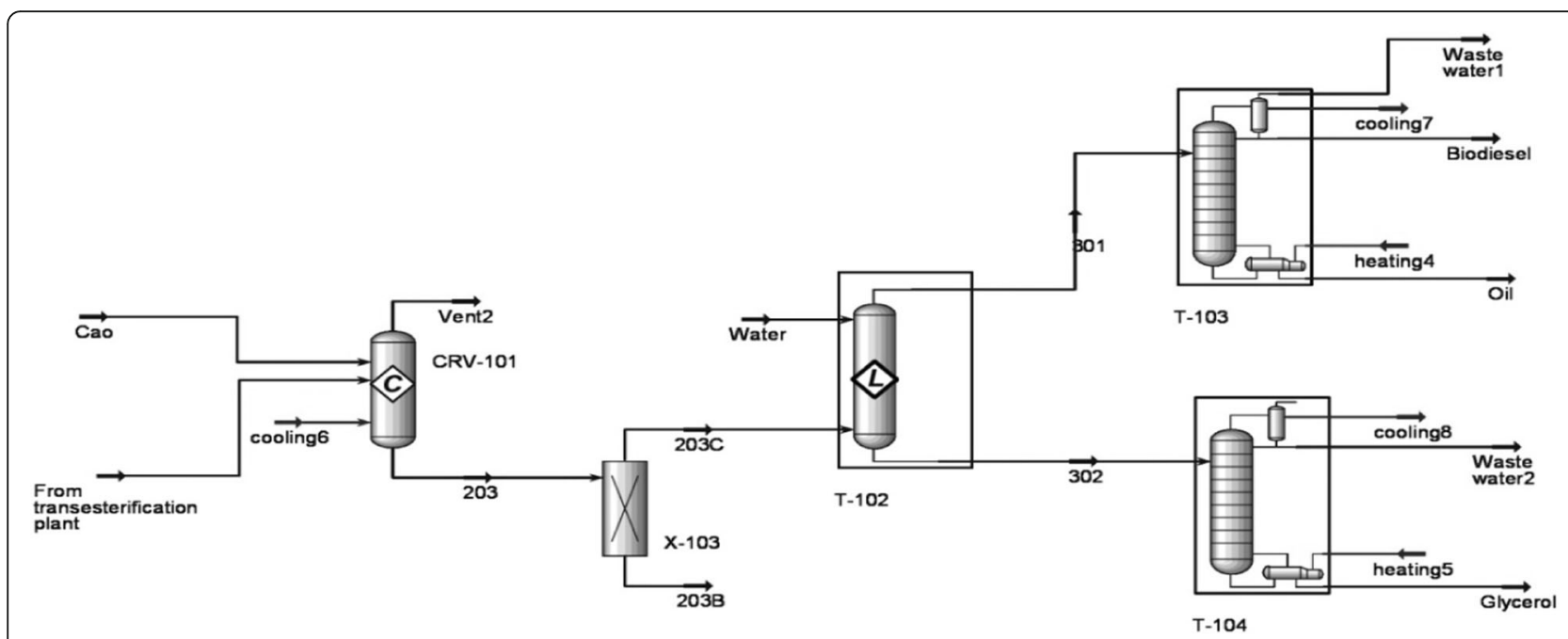

Fig. 5 Product purification flow sheet, where (CRV-101) neutralization tank, (X-103) settling tank, (T-102) water washing tower, (T-103) biodiesel purification distillation tower, and (T-104) glycerol purification distillation tower

ROI is calculating using the following Eq. (1) (Turton et al. 2009), to find it equal to $549.813 \%$.

$$
R O I \%=\frac{\text { NetProfit }}{\text { TCI }} \times 100
$$

\section{Discussion}

Referring to carotenoids and lipid content, it was found that carotenoid extraction must be done as a first step

Table 4 Costs of raw materials, utilities, and products used in the process

\begin{tabular}{ll}
\hline Item & Price \\
\hline Raw materials & 791 \\
Hexane (\$/ton) & \\
Methanol (\$/ton) & 440 \\
Sulfuric acid (\$/ton) & 2398 \\
Calcium oxide (\$/ton) & 150 \\
Water (\$/m $\left.{ }^{3}\right)$ & 0.007 \\
Jojoba oil (\$/ton) & 3000 \\
Products & 1235 \\
Biodiesel (\$/ton) & \\
Cake (\$/ton) & 300 \\
Glycerol (\$/ton) & 1200 \\
Jojoba / Carotenoids (\$/ton) & 4500 \\
Utilities & 0.007 \\
Cooling water $\left.\$ / m^{3}\right)$ & \\
Electricity (\$/kw.h) & \\
Low pressure steam (\$/ton) & 0.04 \\
High pressure steam (\$/ton) & 6.8 \\
\hline
\end{tabular}

for increasing the economic value of the biomass (Christaki et al. 2013). As mentioned in the "results" section, biodiesel yield was $70.6 \%$ with purity of $85 \%$. The results of Doma et al. (2016) that biodiesel from the HRAP will have a high combustion efficiency due to high cetane number and low viscosity. Algal species and growth conditions affect the amount of phenolic compounds in

Table 5 Equipment costs, fixed capital costs, and total capital investment

\begin{tabular}{ll}
\hline Item & Cost (\$) \\
\hline Open pond & $34,619,898$ \\
Centrifuge & $3,422,686$ \\
Decanter centrifuge & $7,964,516$ \\
Solar dryer & 217,474 \\
Reactors & 504,060 \\
Distillation towers & 619,329 \\
Evaporator & 105,264 \\
L-L extractor & 169,920 \\
Pumps & 46,030 \\
Heat exchangers & 118,911 \\
Mixers & 312,721 \\
Gravity settlers & 188,269 \\
Other & $1,160,468$ \\
Purchased cost of equipment (PCE) & $49,449,544$ \\
Contingency = 0.1 $\times$ PCE & $4,944,954$ \\
Auxiliary facility = $0.25 \times$ PCE & $1,236,239$ \\
Fixed capital investment (FCI) & $55,630,738$ \\
Working capital investment (WCI) = 0.15 × FCl & $8,344,611$ \\
Total capital investment (TCI) & $63,975,348$ \\
\hline
\end{tabular}


Table 6 Total manufacturing cost

\begin{tabular}{|c|c|c|}
\hline \multicolumn{2}{|c|}{ Item } & Cost (\$) \\
\hline \multicolumn{3}{|c|}{ Direct manufacturing cost (DMC) } \\
\hline \multicolumn{3}{|l|}{ Raw materials } \\
\hline \multicolumn{2}{|l|}{ Methanol } & 478,368 \\
\hline \multicolumn{2}{|l|}{$\mathrm{H}_{2} \mathrm{SO}_{4}$} & $3,564,387$ \\
\hline \multicolumn{2}{|l|}{ Water } & 2,707 \\
\hline \multicolumn{2}{|l|}{$\mathrm{CaO}$} & 127,320 \\
\hline \multicolumn{2}{|l|}{ Hexane } & 37,968 \\
\hline \multicolumn{2}{|l|}{ Jojoba oil } & $661,269,247$ \\
\hline \multicolumn{3}{|l|}{ Utilities } \\
\hline \multicolumn{2}{|l|}{ Electricity } & $2,619,549$ \\
\hline \multicolumn{2}{|l|}{ L.P.S } & $37,515,025$ \\
\hline \multicolumn{2}{|l|}{ H.P.S } & $8,258,918$ \\
\hline \multicolumn{2}{|l|}{ Cooling water } & 91,818 \\
\hline \multicolumn{2}{|l|}{ Labors } & 546,965 \\
\hline \multicolumn{2}{|l|}{ Maintenance } & $3,337,844$ \\
\hline \multicolumn{2}{|r|}{$0.15 \times$ labor } & 82,045 \\
\hline \multicolumn{2}{|l|}{ Operating supplies } & 500,677 \\
\hline Laboratory charges & $0.15 \times$ labor & 82,045 \\
\hline \multicolumn{2}{|r|}{$0.03 \times \mathrm{TMC}$} & $21,765,444$ \\
\hline \multicolumn{2}{|l|}{ Subtotal } & $78,973,111$ \\
\hline \multicolumn{3}{|c|}{ Indirect manufacturing cost (IDMC) } \\
\hline \multicolumn{2}{|c|}{$\begin{array}{l}\text { Overhead, packaging, and storage } \\
(0.6 \times \text { labor + supervision + maintenance })\end{array}$} & $2,380,112$ \\
\hline Local taxes & $0.015 \times \mathrm{FCl}$ & 834,461 \\
\hline Insurance & $0.005 \times \mathrm{FCl}$ & 278,154 \\
\hline \multicolumn{2}{|l|}{ Subtotal } & $3,492,727$ \\
\hline \multicolumn{2}{|c|}{ Depreciation $0.05 \times \mathrm{FCl}$} & $2,781,537$ \\
\hline \multicolumn{3}{|l|}{ General expenses } \\
\hline \multicolumn{2}{|c|}{ Administrative costs $0.25 \times$ overhead } & 595,028 \\
\hline \multicolumn{2}{|c|}{ Distribution \& selling cost $0.1 \times \mathrm{TMC}$} & $72,551,479$ \\
\hline \multicolumn{2}{|c|}{ Research and development $0.05 \times \mathrm{TMC}$} & $36,275,740$ \\
\hline Subtotal & & $109,422,247$ \\
\hline Total Manufacturir & TMC) & $725,514,791$ \\
\hline
\end{tabular}

algal biomass (Doma et al. 2016). Other studies showed that total phenolic content of the algal strains is responsible for their antioxidant activity (Safafar et al. 2015). Phenolic compounds are biologically active with different health services (Ling et al. 2013).

Flavonoids are strong antioxidants able to react with scavenging oxygen species because of their phenolic hydroxyl group (Rahul et al. 2016). They have multiple activities such as anti-microbial, anti-cancer, and antidiabetic which are making them significant for various pharmaceutical applications (Karamian and Asadbegy
2016). Carbohydrates and protein content in microalgae biomass were studied in Scenedesmus sp. and different microalgae species, and the results showed that some types of polysaccharides have medical services (Ibanez et al. 2012). These polysaccharides have protection against oxidative stress and have efficacy on gastric ulcers, wounds, and constipation (Kraan 2012). Microalgae species have a high content of protein; therefore, they are considered as an untraditional protein source. The algal cells can be providing humans and animals with the essential amino acids due to their ability to synthesize all types of amino acids (Chia et al. 2019).

The project feasibility is estimated through the comparison between the value of the return of investment (ROI) and value of minimum acceptable rate of return (MARR). The results of this project observed that ROI is higher than MARR which was assumed to be $20 \%$.

The stage at which the cost of production equals sales income is known as break-even (Abdo et al. 2016). In the present process, this stage is being at the production of day number 61 and after $1819 \mathrm{t}$ of biodiesel production.

In other words, the biodiesel production from using acid catalyzed transesterification with the extraction of carotenoids using jojoba oil form the algae cell can be considered from the studied cost indicators as a technoeconomic feasible process.

\section{Conclusion}

It can be concluded from the study that the extraction of valuable products contained in the microalgae before the lipid extraction shows an additional profit to the biodiesel production and can turn the process to be highly feasible which is indicated by the high ROI estimated through the preliminary economic evaluation.

The content of total carotenoids extracted with jojoba oil from the microalgae community collected from HRAP constructed to treat municipal wastewater reached 81.44 microgram/g dry microalgae which can be used in cosmetic purposes.

Following this step, a lipid of concentration $5.5 \%$ is further extracted and used for biodiesel production.

In further study, all other valuable products can be also extracted and considered in the economic evaluation.

Added to the products obtained, the microalgae have a great environmental effect in purifying the municipal wastewater by minimizing the organic load of the water which they use as nutrients for their growth.

\section{Acknowledgements}

The authors would like to express their appreciation to the "National Research Center" for the financial support through the Project grant number 10040401 entitled "Biodiesel production from microalgae in stabilization pond for municipal wastewater treatment". 


\section{Authors' contributions}

Sayeda M Abdo (corresponding author) confirms that all listed authors have approved the manuscript before submission, including the names and order of authors, and that all authors receive the submission and all substantive correspondence with editors, as well as the full reviews. Guzine I. El Diwani: Supervisor on the work: Kamel M. El-Khatib: Economic study. Sanaa A. Abo El-Enin: Biodiesel production and phytochemical analysis. Mohammed I. ElGalad: Economic study. Haidy S. Basily: phytochemical analysis. Gamila H. Ali: $\mathrm{Pl}$ of the whole project and supervisor on the work.

\section{Funding}

This study was funded by the National Research Center.

\section{Availability of data and materials}

All data generated or analyzed during this study are included in this published article [and its supplementary information files].

\section{Ethics approval and consent to participate}

Not applicable

\section{Consent for publication}

Not applicable

\section{Competing interests}

The authors declare that they have no competing interests.

\section{Author details}

'Water Pollution Research Department, National Research Centre, Giza, Egypt. ${ }^{2}$ Chemical Engineering and Pilot Plant Department, National Research Centre, Giza, Egypt. ${ }^{3}$ Chemical Engineering Department, Faculty of Engineering, Cairo University, Giza, Egypt. ${ }^{4}$ Egyptian Environment Affairs Agency, Cairo, Egypt.

Received: 13 November 2019 Accepted: 15 July 2020

Published online: 24 September 2020

\section{References}

Abd El-Baky HH, El-Baz FK, El-Baroty GS (2009) Production of phenolic compounds from Spirulina maxima microalgae and its protective effects in vitro toward hepatotoxicity model. Afr J Pharm Pharmacol 3(4):133-139

Abdo SM, Abo El-Enin SA, El-Khatib KM, El-Galad MI, Wahba SZ, El Diwani G, Gamila HA (2016) Preliminary economic assessment of biofuel production from microalgae. Renew Sust Energ Rev 55:1147-1153

Abo El-Enin SA, El-lbiari NN, El-Ardy O, El Diwani G (2016) Variables affecting the in-situ transesterification via ultrasonic from microalgae and comparing with other methods of transesterification. Res J Pharm. Biol Chem Sci 7(1):1000

AspenTech Inc (2005) Hysys(2004).2: Simulation Basis. Aspen Technology, Cambridge

Basily HS, Nassar MM, El Diwani Gl, Abo El-Enin SA (2018) Exploration of using the algal bioactive compounds for cosmeceuticals and pharmaceutical applications. Egyptian Pharmaceut J 17(2) May-August

Bleakley S, Hayes M (2017) Algal proteins: extraction, application, and challenges concerning production. Foods 6:33

Chia SR, Chew KW, Zaid HFM, Chu D-T, Yang T, Show PL (2019) Microalgal protein extraction from Chlorella vulgaris FSP-E using triphasic partitioning technique with sonication. Front Bioeng Biotechnol (06 December)

Christaki E, Bonos E, Giannenas I, Florou-Paneri P (2013) Functional properties of carotenoids originating from algae. J Sci Food Agric 93:5-11

Craggs RJ, Heubeck S, Lundquist TJ, Benemann JR (2011) Algae biofuel from wastewater treatment high rate algal ponds. Water Sci Technol 2011(63): 660-665

de Jesus Raposo MF, de Morais RMSC, de Morais AMMB (2013) Bioactivity and applications of sulphated polysaccharides from marine microalgae. Mar Drugs 11:233-252

Delgadillo-Mirquez L, Lopes F, Taidi B, Pareau D (2016) "Nitrogen and phosphate removal from wastewater with a mixed microalgae and bacteria culture". Biotechnol Rep 11:18-26

Delrue F, Álvarez-Díaz PD, Fon-Sing S, Fleury G, François Sassi I (2016) The environmental biorefinery: using microalgae to Rrmediate wastewater, a winwin paradigm. Energies 9(132):1-19
Doma HS, Abdo SM, Mahmoud RH, El Enin SA, El Diwani G (2016) Production and characterization of biodiesel from microalgae cultivated in municipal wastewater treatment plant. Res J Pharmaceut Biol Chem Sci 7(2):1912-1919

Dubois M, Gilles KA, Hamilton JK, Rebers PA, Smith F (1956) Colorimetric method for determination of sugars and related substances. 28:350-356

Goiris K, Muylaert K, Fraeye I, Foubert I, de Brabanter J, de Cooman L (2012) Antioxidant potential of microalgae in relation to their phenolic and carotenoid content. J Appl Phycol 24:1477-1486

Guedes AC, Amaro HM, Malcata FX (2011) Microalgae as sources of carotenoids. Mar Drugs 9:625-644

Halim R, Gladman B, Danquah MK, Webley PA (2011) Oil extraction from microalga for biodiesel production. Bioresour Technol 2011(102):178-185

Hielscher-Michael S, Griehl C, Buchholz M, Demuth HU, Arnold N, Wessjohann LA (2016) Natural products from microalgae with potential against Alzheimer's disease: sulfolipids are potent glutaminyl cyclase inhibitors. Mar Drugs 14:203

Ibanez E, Herrero M, Mendiola JA, Castro-Puyana M (2012) Extraction and characterization of bioactive compounds with health benefits from marine resources: macro and microalgae, cyanobacteria, and invertebrates. In: Hayes M (ed) Marine bioactive compounds: sources, characterization and applications. Springer Science+Business Media, LLC, New York, pp 55-98

Karamian R, Asadbegy M (2016) Antioxidant Activity, Total phenolic and flavonoid contents of three onobrychis species from Iran. Pharmaceut Sci J 22:112-119

Kern DQ (1950) Process Heat Transfer. McGraw-Hill, New York

Kiepper BH (2013) Microalgae utilization in wastewater treatment, UGA Cooperative Extension Bulletin, p 1419

Kraan S (2012) Algal polysaccharides, novel applications, and outlook. In: Chang C-F (ed) Carbohydrates-Comprehensive Studies on Glycobiology and Glycotechnology. InTech, Rijeka, pp 489-532

Ling ALM, Md S, Yasir PM, Bakar MFA (2013) Antioxidant activity, Total phenolic and flavonoid contents of selected commercial seaweeds of Sabah, Malaysia. Int J Pharm Phytopharmacol Res 3(3):234-238

Lopez CVG, del Carmen Ceron Garcia M, Fernandez FGA, Bustos CS, Chisti Y, Sevilla JMF (2010) Protein measurements of microalgal and cyanobacterial biomass. Bioresour Technol 101:7587-7591

Marazzi F, Bellucci M, Fantasia T, Ficara E, Mezzanotte V (2020) Interactions between microalgae and bacteria in the treatment of wastewater from milk whey processing. Water 12:297

Markou G, Nerantzis E (2013) Microalgae for high-value compounds and biofuels production: a review with focus on cultivation under stress conditions. Biotechnol Adv 31:1532-1542

Mata-Gómez LC, Montañez JC, Méndez-Zavala A, Aguilar CN (2014) Biotechnological production of carotenoids by yeasts: an overview. Microb Cell Factories 13:12 https://doi.org/10.1186/1475-2859-13-12

McCabe WL, Smith JC, Harriott P (1993) Unit operations of chemical engineering, 5th edn. McGraw-Hill, New York

Michalak I, Chojnacka K (2015) Review algae as production systems of bioactive compounds. Eng Life Sci 15:160-176

Molazadeh M, Ahmadzadeh H, Pourianfar HR, Lyon S, Rampelotto PH (2019) The use of microalgae for coupling wastewater treatment with $\mathrm{CO} 2$ biofixation. Front Bioeng Biotechnol 7:42

Pittman JK, Dean AP, Osundeko O (2012) The potential of sustainable algal biofuel production using wastewater resources. Bioresour Technol 102:17-25

Rahul V, Agrawal P, Sharma M, Shukla S (2016) Total phenolics, flavonoids and antioxidant potential of an organic extract of freshwater algal sample collected from a marine lake. Indian J Geo Marine Sci 45(10):1320-1326

Safafar H, van Wagenen J, Møller P, Jacobsen C (2015) Carotenoids, phenolic compounds and tocopherols contribute to the antioxidative properties of some microalgae species grown on industrial wastewater. Mar. Drugs 13: 7339-7356

Sarojini Y, Sujatha B, Lakshminarayana K (2013) Total phenol content and antioxidant activities of ethanolic extracts of two marine brown macroalgae. Int J Curr Sci 8(E):43-49 ISSN 2250-1770

Shashank K, Abhay K (2013) Chemistry and biological activities of flavonoids: an overview. Sci World J 1(1):16

Sinnott RK (2005) Coulson and Richardson's. Chemical Engineering, Volume 6: Chemical Engineering Design, 4th edn. Butterworth-Heinemann, London

Skjanes K, Rebours C, Lindblad P (2013) The potential for green microalgae to produce hydrogen, pharmaceuticals and other high-value products in a combined process. Crit Rev Biotechnol 33(2):172-215 
Turton R, Bailie RC, Whiting WB, Shaeiwitz JA (2009) Analysis, synthesis, and design of chemical processes, 3rd edn. Prentice Hall, New Jersey

Whitton R, Ometto F, Pidou M, Jarvis P, Villa R, Jefferson B (2015) Microalgae for municipal wastewater nutrient remediation: mechanisms, reactors and outlook for tertiary treatment. Environ Technol Rev 4(1):133-148

Wollmann F, Dietze S, Ackermann J-U, Bley T, Walther T, Steingroewer J, Krujatz F (2019) Microalgae wastewater treatment: biological and technological approaches. Eng Life Sci 19:860-871

Yen H-W, Hu I-C, Chen C-Y, Ho S-H, Lee D-J, Chang J-S (2013) "Microalgae-based biorefinery - From biofuels to natural products". Bioresour Technol 135:166-174

Yoshitani J (2014) Algae integrated aquaculture. Wisconsin Aquacult Conf

Zhang S, Zhang XYH, Chu C, Zheng K, Meiting J, Liu L (2019) Liquefaction of biomass and upgrading of bio-oil: a review. Molecules 24:2250

Zhang Y, Dube MA, McLean DDL, Kates M (2003) Biodiesel production from waste cooking oil: 1. Process design and technological assessment. Bioresour Technol 89(1):1-16

\section{Publisher's Note}

Springer Nature remains neutral with regard to jurisdictional claims in published maps and institutional affiliations.

\section{Submit your manuscript to a SpringerOpen ${ }^{\circ}$ journal and benefit from:}

- Convenient online submission

- Rigorous peer review

- Open access: articles freely available online

High visibility within the field

- Retaining the copyright to your article

Submit your next manuscript at $\boldsymbol{\nabla}$ springeropen.com 